\title{
Trace Elements in Different Species of Cetacean from Rio de Janeiro Coast
}

\author{
Tércia G. Seixas, ${ }^{* a}$ Helena A. Kehrig, ${ }^{b}$ Ana Paula M. Di Beneditto, ${ }^{c}$ \\ Cristina M. M. Souza, ${ }^{c}$ Olaf Malm $^{b}$ and Isabel Moreira ${ }^{a}$
}

\author{
${ }^{a}$ Departamento de Química, Pontifícia Universidade Católica do Rio de Janeiro, \\ 22453-900 Rio de Janeiro-RJ, Brazil
}

${ }^{b}$ Instituto de Biofísica Carlos Chagas Filho, Universidade Federal do Rio de Janeiro, 21941-902 Rio de Janeiro-RJ, Brazil

${ }^{c}$ Centro de Biociências e Biotecnologia, Universidade Estadual do Norte Fluminense, 28013-602 Campos dos Goytacazes-RJ, Brazil

\begin{abstract}
Neste estudo avaliou-se a influência de alguns parâmetros ecológicos e biológicos sobre a acumulação dos elementos-traço ( $\mathrm{As}, \mathrm{Cd}, \mathrm{Cu}, \mathrm{Pb}, \mathrm{Se}$ e Ag) no fígado de três espécies de cetáceos, sendo duas de hábito costeiro (Pontoporia blainvillei e Sotalia guianensis) e uma de hábito oceânico (Stenella frontalis), que foram acidentalmente capturados na costa norte do estado do Rio de Janeiro. Diferenças inter-espécies foram observadas no padrão de acumulação dos elementos-traço, $\mathrm{Cd}$ e $\mathrm{Pb}\left(5,12 \pm 0,74 \mu \mathrm{g} \mathrm{g}^{-1}\right.$ e 21,25 $\pm 1,35 \mu \mathrm{g} \mathrm{g}^{-1}$, respectivamente). Entretanto, as três espécies de cetáceo, $S$. guianensis, P. blainvillei e $S$. frontalis apresentaram concentrações hepáticas de As, $\mathrm{Cu}$ e Ag similares. O sexo dos indivíduos não influiu na bioacumulação dos elementos. O comprimento total influenciou na acumulação dos elementos-traço no fígado de acordo com a espécie de cetáceo. S. guianensis, que co-habita o mesmo ambiente que a espécie P. blainvillei, apresentou uma diferença significativa na concentração hepática de selênio $\left(20,70 \pm 32,22 \mu \mathrm{g} \mathrm{g}^{-1} \mathrm{e}\right.$ $3,24 \pm 2,02 \mu \mathrm{g} \mathrm{g}^{-1}$, respectivamente). A partir dessas observações pode-se concluir que condições ambientais e parâmetros biológicos, tais como comprimento total e principalmente a preferência alimentar, influenciaram significativamente a acumulação de elementos traço no fígado dessas espécies de cetáceos.
\end{abstract}

The present work tested whether ecological and biological parameters have an influence on the accumulation of trace elements ( $\mathrm{As}, \mathrm{Cd}, \mathrm{Cu}, \mathrm{Pb}, \mathrm{Se}$ and $\mathrm{Ag}$ ) by the liver of three cetaceans species: two species of coastal habit (Pontoporia blainvillei and Sotalia guianensis) and one of oceanic habit (Stenella frontalis), that were incidentally caught in fishing nets along the north of Rio de Janeiro coast. Inter-species difference was observed on the accumulation of $\mathrm{Cd}$ and $\mathrm{Pb}$ $\left(5.12 \pm 0.74 \mu \mathrm{g} \mathrm{g}^{-1}\right.$ and $21.25 \pm 1.35 \mu \mathrm{g} \mathrm{g}^{-1}$, respectively). However, the three cetacean species, $S$. guianensis, P. blainvillei and $S$. frontalis presented similar hepatic concentrations of $\mathrm{As}, \mathrm{Cu}$ and $\mathrm{Ag}$. No gender differences were found on the bioaccumulation of trace elements. Hepatic trace element accumulation was influenced by body length, according to the cetacean species. $S$. guianensis, which co-habits the same coastal marine environment that $P$. blainvillei species, presented a significant difference between hepatic selenium concentration $\left(20.70 \pm 32.22 \mu \mathrm{g} \mathrm{g}^{-1}\right.$ and $3.24 \pm 2.02 \mu \mathrm{g} \mathrm{g}^{-1}$, respectively). Based on these results, it is possible to conclude that, not only the different environmental conditions, but also total length and mainly the feeding habit influenced the accumulation of trace elements by the liver of these cetacean species.

Keywords: trace elements, liver of marine dolphin species, biological parameters, Rio de Janeiro coast, GF-AAS

\section{Introduction}

The industrial and urban development observed in the last decades greatly increased the fluxes of various chemical

\footnotetext{
*e-mail: terciaguedes@gmail.com
}

contaminants and pollutants, such as, organic matter, oil and also a great number of others compounds, including trace elements, to the marine environment. ${ }^{1,2}$ Some elements such as selenium, arsenic and copper are of ecological and biological interest because they are required as essential nutrients in low concentrations for marine organisms and 
can be considered detrimental at excessive levels. ${ }^{3,4}$ However, living organisms require varying amounts of metals. Iron, cobalt, copper, manganese, molybdenum, and zinc are required by mammals. Other heavy metals such as mercury, silver, and lead are toxic without any vital or beneficial effect on organisms, and their accumulation over time in the bodies of animals can cause serious illness. ${ }^{5}$ Certain elements that are normally toxic are, for certain organisms or under certain conditions, beneficial. Examples include vanadium, tungsten, and even cadmium. ${ }^{6}$

Predatory marine mammals have high potential for accumulating some elements since they have relatively long life spans, and generally occupy a high trophic level in the marine food chain. ${ }^{7,8}$ They represent the ultimate biological "sink" for many persistent pollutants ${ }^{9}$ and also have been considered good bioindicators of environmental contamination. ${ }^{10}$ The analysis of tissues from different species of whales and dolphins has been used as a tool for the assessment of marine pollution by trace elements. ${ }^{7,8,11}$ Generally, marine mammals such as cetaceans species present high concentration of these elements in the liver due to the role played by this organ in terms of pollutant bio-transformation, metabolizing nutrients and essential elements as well as removing some non-essential elements and toxins from the bloodstream. ${ }^{12}$

The study of trace elements in marine mammals is in its infancy in Brazil where few studies documented their concentrations in the tissues of cetaceans species with coastal habits such as Sotalia guianensis, Pontoporia blainvillei and oceanic habits such as Stenella frontalis. ${ }^{7,11,13-17}$ Furthermore, extensive studies of $\mathrm{As}, \mathrm{Cd}, \mathrm{Cu}, \mathrm{Pb}, \mathrm{Se}$ and Ag concentrations in cetaceans have been carried out in Northern Hemisphere ${ }^{5,8,10,12,18-30}$ but relatively little is known about contaminant levels in Southern Hemisphere cetaceans. ${ }^{31-35}$ Then, the present research adds new insight to and complements the existing studies.

This study assesses: (i) trace element (As, $\mathrm{Cd}, \mathrm{Cu}, \mathrm{Pb}$, Se and Ag) concentrations in the liver of three cetacean species, Sotalia guianensis (estuarine dolphin), Pontoporia blainvillei (franciscana dolphin) and Stenella frontalis (Atlantic spotted dolphin) incidentally caught in fishing nets along the North coast of the Rio de Janeiro State (Brazil) and, (ii) the influence of gender, body length and habitat on their hepatic trace element content. In this region, the coastal dolphins, Sotalia guianensis and Pontoporia blainvillei, are particularly vulnerable to anthropogenic activities. ${ }^{36}$ However, the problems facing marine mammal populations are likely multi-factorial and include effects from habitat destruction, pollutants, municipal runoff, global climate change, fishing activities, and over-harvesting of marine research. ${ }^{37}$

\section{Experimental}

\section{Sampling and sampling areas}

Liver samples were collected from 43 individuals of cetaceans species that are sympatric to the North coast of the Rio de Janeiro State ( $21^{\circ} 18^{\prime}$ S $\left.-22^{\circ} 25^{\prime} \mathrm{S}\right)$, southeastern Brazil (Figure 1), and present different feeding habits and inhabit distinct regions of the continental shelf. The animals were incidentally caught in fishing nets along the open coastal areas from 1998 to 2005. The North coast of the Rio de Janeiro State is permanently influenced by Paraiba do Sul River that is considered the most important fluvial influx, with high sedimentary and freshwater influx, of the coast of Rio de Janeiro State. ${ }^{38}$ Biological parameters from cetaceans species analyzed in this study are presented in Table 1.

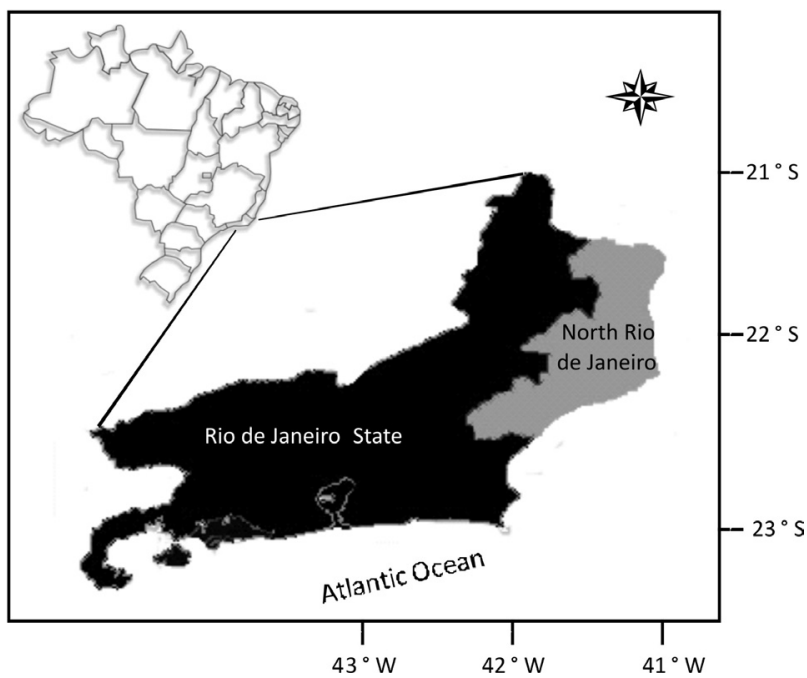

Figure 1. Location of the Northern Rio de Janeiro (Brazil), where dolphin species were caught.

Table 1. Biological parameters from cetaceans (Sotalia guianensis, Pontoporia blainvillei and Stenella frontalis) analyzed in this study

\begin{tabular}{lccc}
\hline Species & $\begin{array}{c}\text { Number of } \\
\text { individuals }\end{array}$ & Sex & $\begin{array}{c}\text { Body length } \\
\text { (min-max in cm) }\end{array}$ \\
\hline $\begin{array}{l}\text { Sotalia } \\
\text { guianensis }\end{array}$ & 12 & Male & $86.0-200.0$ \\
& 8 & Female & $160.0-196.0$ \\
Pontoporia & 1 & Not identified & - \\
blainvillei & 11 & Male & $82.0-123.0$ \\
& 6 & Female & $68.0-147.0$ \\
Stenella frontalis & 1 & Not identified & 103.0 \\
& 1 & Male & 170.0 \\
& 1 & Female & 145.0 \\
& 2 & Not identified & - \\
\hline
\end{tabular}


Pontoporia blainvillei (Gervais \& D' Orbigny, 1844) and Sotalia guianensis (van Bénéden, 1862) appears to be preferentially ichthyophagous species. However, $P$. blainvillei feeds mainly on teleost fish (up to $10 \mathrm{~cm}$ ) and cephalopods ${ }^{39}$ while $S$. guianensis feeds mainly on large teleost fish (from 32 up to $107 \mathrm{~cm}$ ). ${ }^{36}$ Stenella frontalis (Cuvier, 1828) can be considered primarily a teuthophagous species that may move onto the continental shelf of southeastern Brazil to capture prey and can be considered opportunistic predator, feeding on those most abundant species. $^{40}$

The samples were supplied by the Biological Specimen Banking from the Bioscience and Biotechnology Center (UENF). After dissection, samples were stored in individual polyethylene bags and kept frozen $\left(-20{ }^{\circ} \mathrm{C}\right)$ until freezedrying process. They lost around $70 \%$ of their water content.

\section{Instrumentation}

Total arsenic, cadmium, copper, lead, selenium and silver were determined by graphite furnace atomic absorption spectrometry (GF-AAS), using an Analytik Jena spectrometer ZEEnit 60 (Jena, Germany) equipped with Zeeman-effect background correction and auto sampler MPE-52 (Analytik Jena). Integrated contact tubes with PIN platforms (Analytik Jena, part no. 407-152.011) were also used. The protective and carrier gas was argon $(99.96 \%$, Aga, Rio de Janeiro, Brazil) at a flow rate of $2 \mathrm{~L} \mathrm{~h}^{-1}$. The operating parameters and the instrumental settings were adjusted according to the manufacturer's recommendations, unless otherwise specified. All measurements were based on integrated absorbance, with a $5 \mathrm{~s}$ integration time.

\section{Analytical procedure}

Dried liver samples $(100 \mathrm{mg})$ were acid digested with $2 \mathrm{~mL}$ of $65 \%$ nitric acid (Merck p.a.) in a screwcapped vessel, during $24 \mathrm{~h}$. The vessel was then heated to $60{ }^{\circ} \mathrm{C}$ for $120 \mathrm{~min}$ in a water bath. After cooling, the digested samples were made up to a known volume $(1 \mathrm{~mL})$ with high purity deionizer water $(18.2 \mathrm{M} \Omega \mathrm{cm})$ from a Milli-Q system and trace element concentrations in the acid digested solution were determined by GF-AAS. All chemicals used were of analytical reagent grade. Palladium nitrate was used as a chemical modifier and hence added to each solution to be analyzed for As, Cd, $\mathrm{Pb}, \mathrm{Se}$ and $\mathrm{Ag}$. It was prepared from a stock solution of palladium nitrate (Merck No. B9366989 710), modifier for graphite furnace AAS. Arsenic, $\mathrm{Cd}, \mathrm{Cu}, \mathrm{Pb}, \mathrm{Se}$ and $\mathrm{Ag}$ stock solutions, $1000 \mathrm{mg} \mathrm{L}^{-1}$, were prepared by adequate dilution of Titrisol ${ }^{\circledR}$ ampoules from Merck. Standard solutions in the working range were prepared from the stock solutions, using $0.2 \%$ (v/v) $\mathrm{HNO}_{3}$. Analytical blanks were prepared in a similar way without insertion of the analytes. The instrumental conditions and the temperature programs used are shown in Table 2. Optimization of the analytical protocol and quality assurance tests were carried out using the reference materials (CRM) of fish tissues from the National Research Council-Canada (DORM-2-dogfish muscle sample, DOLT-2-dogfish liver sample and TORT-2-lobster hepatopancreas).

\section{Statistical analysis}

Statistical analyses were performed using STATISTICA ${ }^{\circledR}$ 7.0 for Windows (StatSoft, Inc. 1984-2004, USA). Data were tested for normal distributions (Shapiro-Wilk's test) and nonparametric were then applied. The analysis of variance was done by Kruskal-Wallis ANOVA followed by a post-hoc test (Mann-Whitney $U$-test). The $U$-test was used to compare the concentrations of the trace elements in the liver of dolphins with different feeding habits and inhabiting different regions of the Brazilian continental shelf. A Spearman correlation coefficient $(\mathrm{R})$ was carried out to verify the relation between the biological parameters (gender and body length) and the trace elements concentration. The Discriminant Function Analysis (DFA) was applied to compare the concentration of trace elements (variables) between the three dolphin species (groups) and also, to visualize the overall main trends. A $p$ value of less than 0.05 was chosen to indicate statistical significance. Values are presented as mean and range (minmax) in a dry weight basis.

\section{Results and Discussion}

Limits of detection, limits of quantification and validation of the analytical method

The limits of detection (LOD) and the limits of quantification (LOQ) were calculated based on the standard deviation of 20 readings obtained for the analytical blanks and the slopes of the analytical curves $(\mathrm{LOD}=3 \sigma / \mathrm{slope}$ and $\mathrm{LOQ}=10 \sigma /$ slope). Their values were: 0.62 and $1.97 \mu \mathrm{g} \mathrm{L}^{-1}$ for As; 0.02 and $0.06 \mu \mathrm{g} \mathrm{L}^{-1}$ for $\mathrm{Cd}$; 0.33 and $1.05 \mu \mathrm{g} \mathrm{L}^{-1}$ for $\mathrm{Cu} ; 3.80$ and $12.70 \mu \mathrm{g} \mathrm{L}^{-1}$ for $\mathrm{Pb}$; 0.87 and $2.77 \mu \mathrm{g} \mathrm{L}^{-1}$ for $\mathrm{Se}$, and 0.08 and $0.26 \mu \mathrm{g} \mathrm{L} \mathrm{L}^{-1}$ for $\mathrm{Ag}$, respectively. For $100 \mathrm{mg}$ of dry sample and $2 \mathrm{~mL}$ of final volume, these values correspond to 12.4 and $39.4 \mu \mathrm{g} \mathrm{As} \mathrm{kg}{ }^{-1}$, 0.4 and $1.2 \mu \mathrm{g} \mathrm{Cd} \mathrm{kg}^{-1}, 6.6$ and $21.0 \mu \mathrm{g} \mathrm{Cu} \mathrm{kg}{ }^{-1}, 76$ and

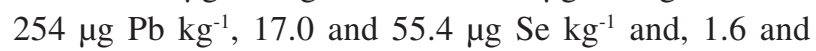
$5.2 \mu \mathrm{g} \mathrm{Ag} \mathrm{kg}{ }^{-1}$. 
Table 2. Instrumental parameters and temperature programs for the determination of $\mathrm{As}, \mathrm{Cd}, \mathrm{Cu}, \mathrm{Pb}, \mathrm{Se}$ and $\mathrm{Ag}$ in cetaceans' liver samples by GF-AAS (sample volume $20 \mu \mathrm{L}$ )

\begin{tabular}{|c|c|c|c|c|c|c|}
\hline & $\mathrm{Se}$ & As & $\mathrm{Ag}$ & $\mathrm{Cd}$ & $\mathrm{Cu}$ & $\mathrm{Pb}$ \\
\hline \multicolumn{7}{|l|}{ Instrumental conditions } \\
\hline Wavelength / nm & 196.0 & 193.7 & 328.1 & 228.8 & 324.8 & 283.3 \\
\hline Spectral resolution / $\mathrm{nm}$ & 1.2 & 0.5 & 0.8 & 0.8 & 0.8 & 0.5 \\
\hline Lamp current / mA & 6.0 & 10.0 & 4.0 & 4.0 & 3.0 & 8.0 \\
\hline \multicolumn{7}{|l|}{ Furnace programs } \\
\hline \multicolumn{7}{|l|}{ Drying 1} \\
\hline Temperature $/{ }^{\circ} \mathrm{C}$ & 90 & 90 & 90 & 90 & 90 & 90 \\
\hline $\operatorname{Ramp} /\left({ }^{\circ} \mathrm{C} \mathrm{s}^{-1}\right)$ & 10 & 10 & 10 & 10 & 10 & 1 \\
\hline Hold / s & 15 & 15 & 10 & 5 & 5 & 10 \\
\hline Gas flow / $\left(\mathrm{L} \mathrm{h}^{-1}\right)$ & 2 & 2 & 2 & 2 & 2 & 2 \\
\hline \multicolumn{7}{|l|}{ Drying 2} \\
\hline Temperature $/{ }^{\circ} \mathrm{C}$ & 120 & 120 & 105 & 105 & 105 & 120 \\
\hline $\operatorname{Ramp} /\left({ }^{\circ} \mathrm{C} \mathrm{s}^{-1}\right)$ & 15 & 15 & 7 & 7 & 7 & 20 \\
\hline Hold / s & 25 & 25 & 10 & 30 & 30 & 20 \\
\hline Gas flow / $\left(\mathrm{L} \mathrm{h}^{-1}\right)$ & 2 & 2 & 2 & 2 & 2 & 2 \\
\hline \multicolumn{7}{|l|}{ Drying 3} \\
\hline Temperature $/{ }^{\circ} \mathrm{C}$ & - & - & 120 & 120 & 120 & - \\
\hline Ramp / $\left({ }^{\circ} \mathrm{C} \mathrm{s}^{-1}\right)$ & - & - & 10 & 15 & 15 & - \\
\hline Hold / s & - & - & 10 & 10 & 10 & - \\
\hline Gas flow / $\left(\mathrm{L} \mathrm{h}^{-1}\right)$ & - & - & 2 & 2 & 2 & - \\
\hline \multicolumn{7}{|l|}{ Pyrolysis 1} \\
\hline Temperature $/{ }^{\circ} \mathrm{C}$ & 500 & 500 & 500 & - & - & - \\
\hline Ramp / $\left({ }^{\circ} \mathrm{C} \mathrm{s}^{-1}\right)$ & 7 & 7 & 10 & - & - & - \\
\hline Hold / s & 20 & 20 & 20 & - & - & - \\
\hline Gas flow / $\left(\mathrm{L} \mathrm{h}^{-1}\right)$ & 2 & 2 & 2 & - & - & - \\
\hline \multicolumn{7}{|l|}{ Pyrolysis 2} \\
\hline Temperature $/{ }^{\circ} \mathrm{C}$ & 1200 & 1200 & 800 & 900 & 1000 & 900 \\
\hline Ramp / $\left({ }^{\circ} \mathrm{C} \mathrm{s}^{-1}\right)$ & 30 & 30 & 30 & 1000 & 400 & 10 \\
\hline Hold / s & 30 & 30 & 30 & 10 & 10 & 20 \\
\hline Gas flow / $\left(\mathrm{L} \mathrm{h}^{-1}\right)$ & 2 & 2 & 2 & 2 & 2 & 2 \\
\hline \multicolumn{7}{|l|}{ Auto-zero } \\
\hline Temperature $/{ }^{\circ} \mathrm{C}$ & 1200 & 1200 & 800 & 900 & 1000 & 900 \\
\hline Ramp / $\left({ }^{\circ} \mathrm{C} \mathrm{s}^{-1}\right)$ & 0 & 0 & 0 & 0 & 0 & 0 \\
\hline Hold / s & 6 & 6 & 6 & 6 & 6 & 5 \\
\hline Gas flow / $\left(\mathrm{L} \mathrm{h}^{-1}\right)$ & Stop & Stop & Stop & Stop & Stop & Stop \\
\hline \multicolumn{7}{|l|}{ Atomize } \\
\hline Temperature $/{ }^{\circ} \mathrm{C}$ & 2200 & 2200 & 1900 & 1900 & 2200 & 2100 \\
\hline Ramp / $\left({ }^{\circ} \mathrm{C} \mathrm{s}^{-1}\right)$ & 2500 & 2600 & 2000 & 2500 & 2500 & 1500 \\
\hline Hold / s & 6 & 6 & 3 & 5 & 5 & 2 \\
\hline Gas flow / $\left(\mathrm{L} \mathrm{h}^{-1}\right)$ & Stop & Stop & Stop & Stop & Stop & Stop \\
\hline \multicolumn{7}{|l|}{ Cleanout } \\
\hline Temperature $/{ }^{\circ} \mathrm{C}$ & 2500 & 2500 & 2500 & 2000 & 2400 & 2400 \\
\hline Ramp / $\left({ }^{\circ} \mathrm{C} \mathrm{s}^{-1}\right)$ & 1000 & 1000 & 1000 & 1000 & 1000 & 1000 \\
\hline Hold / s & 5 & 5 & 4 & 3 & 4 & 4 \\
\hline Gas flow / $\left(\mathrm{L} \mathrm{h}^{-1}\right)$ & 2 & 2 & 2 & 2 & 2 & 2 \\
\hline
\end{tabular}


The experimental results for trace elements in the certified reference materials (CRM) from the NRCC (DORM-2, DOLT-2 and TORT-2) presented good agreement with the certified values (Table 3 ). The standard deviation found for experimental values were low and close to those found for certified values, indicating the high repeatability of the analytical method (Table 3). The relative standard deviation (SD/mean) for each reference sample was lower than $10 \%$, showing that the analytical procedure was suitable. According to these results, we can conclude that the analytical method was accurate and precise for trace element determination in biological tissues.

Table 3. Analytical results for the determination of certified marine reference materials

\begin{tabular}{lcc}
\hline & $\begin{array}{c}\text { Certified Values } \\
\left(\mathrm{mg} \mathrm{kg}^{-1}\right)^{*}\end{array}$ & $\begin{array}{c}\text { Found Values } \\
\left(\mathrm{mg} \mathrm{kg}^{\mathrm{a}}\right)^{*}\end{array}$ \\
\hline $\mathrm{DORM} \mathrm{-}$ & $1.40 \pm 0.09$ & $1.34 \pm 0.19$ \\
$\mathrm{Se}$ & $0.041 \pm 0.013$ & $0.038 \pm 0.005$ \\
$\mathrm{Ag}$ & $18.0 \pm 1.1$ & $18.7 \pm 1.9$ \\
$\mathrm{As}$ & $0.043 \pm 0.008$ & $0.036 \pm 0.005$ \\
$\mathrm{Cd}$ & $2.34 \pm 0.16$ & $1.95 \pm 0.27$ \\
$\mathrm{Cu}$ & & \\
$\mathrm{TORT}-2$ & $5.63 \pm 0.67$ & $5.24 \pm 0.42$ \\
$\mathrm{Se}$ & $21.6 \pm 1.8$ & $21.3 \pm 1.1$ \\
$\mathrm{As}$ & $26.7 \pm 0.6$ & $26.6 \pm 0.5$ \\
$\mathrm{Cd}$ & $106 \pm 10$ & $99.6 \pm 9.2$ \\
$\mathrm{Cu}$ & $0.35 \pm 0.13$ & $0.36 \pm 0.02$ \\
$\mathrm{~Pb}$ & & \\
$\mathrm{DOLT}-2$ & $0.608 \pm 0.032$ & $0.590 \pm 0.013$ \\
$\mathrm{Ag}$ & $0.22 \pm 0.02$ & $0.20 \pm 0.09$ \\
$\mathrm{~Pb}$ &
\end{tabular}

aThe found values are reported as mean of a total of 8 determinations for each trace-element with $95 \%$ confidence intervals. * All values are expressed as dry mass.

\section{Liver samples}

The concentrations of trace elements (on a dry mass basis) in the liver of cetaceans are summarized in Table 4. Some of the trace elements are essential (As, $\mathrm{Cu}$ and $\mathrm{Se}$ ) and their concentrations are expected to be regulated; however, it should be taken into consideration that the data here refer to stranded animals, thus, not necessarily representative of healthy conditions. ${ }^{41}$ Other elements $(\mathrm{Cd}, \mathrm{Pb}$ and $\mathrm{Ag})$ are non-essential and are expected to vary in a wide range of concentration, reflecting exposure to environmental levels and feeding behavior. ${ }^{41}$ The case of Se is peculiar. It is an essential element, yet it is subjected to large variations related to high mercury levels. ${ }^{17,42}$
The analysis of variance (Kruskal-Wallis ANOVA) showed differences in hepatic trace element concentrations between the cetaceans analyzed in this study. Hepatic concentrations of $\mathrm{Se}(p=0.015), \mathrm{Cd}(p=0.032)$ and $\mathrm{Pb}$ $(p=0.001)$ were significantly different among the three cetaceans species ( $S$. guianensis, P. blainvillei and $S$. frontalis). On the other hand, no significant differences $(p>0.05)$ in the hepatic As, $\mathrm{Cu}$ and $\mathrm{Ag}$ were observed between these species. Regarding to the cetaceans with coastal habit, S. guianensis presented higher hepatic Se concentration than those found in P. blainvillei. Conversely $\mathrm{Cd}$ and $\mathrm{Pb}$ concentrations in the liver of the cetacean species that occur on continental shelf ( $S$. frontalis) were significantly higher than those found for $S$. guianensis $(p<0.001)$ and P. blainvillei $(p<0.001)$. Probably, the species differences might be associated with their different feeding habits and also for inhabiting different regions of the Brazilian continental shelf. According to Di Beneditto and Ramos, ${ }^{39}$ P. blainvillei feeds mainly on teleost fish (up to $10 \mathrm{~cm}$ ) and cephalopods, while $S$. guianensis feeds mainly on large teleost fish (from 32 up to $107 \mathrm{~cm})^{36}$ and both are small cetaceans with typically coastal habit and sympatric in South-eastern Brazil. ${ }^{43}$ Conversely, $S$. frontalis has preference for squids as food item in the southeastern Brazil and also is sympatric in this region..$^{40}$ These cetacean species regularly inhabit nearshore shallow areas, although sightings were also reported in deeper waters. Individuals of $S$. frontalis were sighted in depths ranging from the upper continental shelf $(20 \mathrm{~m})$ to the slope area $(961 \mathrm{~m}){ }^{44}$

In this study, concentrations of essential and nonessential elements found in the liver of cetaceans species were of the same order of magnitude as those reported in previous studies with the same species from the South American coast (Table 4), but hepatic copper concentration in the three cetaceans species (S. guianensis, P. blainvillei and $S$. frontalis) from the southeastern Brazilian coast, was lower than those found in samples from the southern coast of Brazil $^{10}$ (Table 4) and Argentine coast ${ }^{32,34}$ (Table 4).

Cadmium concentrations in the liver of $P$. blainvillei from the coastal areas of Argentina ${ }^{32,34}$ (Table 4) and $S$. frontalis from the Brazilian southern coast ${ }^{7}$ (Table 4) presented higher concentrations than those found in the liver of these dolphin species from the northern coast of Rio de Janeiro (Brazil). The same behavior was observed for copper, selenium and silver in the liver of $S$. frontalis ${ }^{7}$ (Table 4) where individuals from the Brazilian southern coast ${ }^{7}$ also presented the highest hepatic concentration of these elements. A regional difference on hepatic cadmium and selenium concentration in P. blainvillei was also observed and it was well discussed by Seixas et al. ${ }^{11}$ 
Table 4. Mean concentrations of essential and non essential elements ( $\mu \mathrm{g} \mathrm{g}^{-1}$ dry mass) in the liver of cetacean species from South America coast

\begin{tabular}{|c|c|c|c|c|c|c|c|c|}
\hline \multirow[b]{2}{*}{ Species (N) } & \multicolumn{3}{|c|}{$\begin{array}{c}\text { Essential Elements } \\
\text { Mean } \pm \text { SD (min-max })\end{array}$} & \multicolumn{3}{|c|}{$\begin{array}{l}\text { Non Essential Elements } \\
\text { Mean } \pm \text { SD (min-max) }\end{array}$} & \multirow[b]{2}{*}{ Area } & \multirow[b]{2}{*}{ Reference } \\
\hline & $\mathrm{Se}$ & As & $\mathrm{Cu}$ & $\mathrm{Cd}$ & $\mathrm{Pb}$ & $\mathrm{Ag}$ & & \\
\hline A (21) & $\begin{array}{l}20.70 \pm 32.22 \\
(1.38-115.32)\end{array}$ & $\begin{array}{l}1.11 \pm 0.58 \\
(0.28-2.40)\end{array}$ & $\begin{array}{l}26.48 \pm 19.89 \\
(13.44-83.77)\end{array}$ & $\begin{array}{c}0.39 \pm 0.37 \\
(0.001-1.48)\end{array}$ & $\begin{array}{l}1.55 \pm 0.75 \\
(0.74-2.73)\end{array}$ & $\begin{array}{l}1.00 \pm 1.34 \\
(0.11-4.61)\end{array}$ & $\begin{array}{l}\text { Southeast } \\
\text { Brazil }\end{array}$ & This study \\
\hline A (11) & - & - & - & $\begin{array}{l}0.22 \pm 0.38 \\
(0.01-1.32)\end{array}$ & $\begin{array}{l}0.11 \pm 0.02 \\
(0.10-0.12)\end{array}$ & - & $\begin{array}{l}\text { Northeast } \\
\text { Brazil }\end{array}$ & 14 \\
\hline A (15) & $\begin{array}{c}34.0 \\
(1.98-247.19)\end{array}$ & - & - & - & - & - & $\begin{array}{l}\text { Southeast } \\
\text { Brazil }\end{array}$ & 15 \\
\hline A (20) & $\begin{array}{c}38.00 \pm 49.00 \\
(3.00-170.0)\end{array}$ & $\begin{array}{l}0.83 \pm 0.32 \\
(0.27-1.60)\end{array}$ & $\begin{array}{l}157.0 \pm 436.0 \\
(14.5-1970.0)\end{array}$ & $\begin{array}{c}0.65 \pm 0.75 \\
(0.009-2.19)\end{array}$ & $\begin{array}{l}0.07 \pm 0.05 \\
(0.02-0.20)\end{array}$ & $\begin{array}{l}1.90 \pm 1.30 \\
(0.28-4.90)\end{array}$ & $\begin{array}{l}\text { South } \\
\text { Brazil }\end{array}$ & 7 \\
\hline B (18) & $\begin{array}{l}3.24 \pm 2.00 \\
(0.84-9.05)\end{array}$ & $\begin{array}{l}1.10 \pm 0.79 \\
(0.21-2.75)\end{array}$ & $\begin{array}{l}25.64 \pm 41.28 \\
(3.13-188.75)\end{array}$ & $\begin{array}{c}0.55 \pm 0.97 \\
(0.001-3.03)\end{array}$ & $\begin{array}{l}0.67 \pm 0.45 \\
(0.15-1.60)\end{array}$ & $\begin{array}{l}0.60 \pm 0.63 \\
(0.04-2.06)\end{array}$ & $\begin{array}{l}\text { Southeast } \\
\text { Brazil }\end{array}$ & This study \\
\hline B (7) & - & - & $52.80 \pm 10.89$ & $10.89 \pm 4.62$ & - & - & Argentina & 32 \\
\hline B (18) & - & - & 62.71 & 7.49 & - & - & Argentina & 34 \\
\hline B (17) & - & - & $(13.20-69.31)$ & $(\approx 0.0-2.08)$ & - & - & $\begin{array}{l}\text { Southeast } \\
\text { Brazil }\end{array}$ & 13 \\
\hline B (23) & $\begin{array}{c}9.10 \pm 5.50 \\
(3.50-30.00)\end{array}$ & $\begin{array}{l}1.20 \pm 0.40 \\
(0.14-2.40)\end{array}$ & $\begin{array}{c}44.50 \pm 89.00 \\
(14.7-446.0)\end{array}$ & $\begin{array}{c}0.40 \pm 0.78 \\
(0.004-3.87)\end{array}$ & $\begin{array}{c}0.03 \pm 0.02 \\
(0.007-0.070)\end{array}$ & $\begin{array}{l}2.40 \pm 4.10 \\
(0.28-20.0)\end{array}$ & South Brazil & 7 \\
\hline B (13) & $\begin{array}{c}11.06 \pm 13.77 \\
(3.69-54.33)\end{array}$ & $\begin{array}{l}1.69 \pm 0.58 \\
(1.02-3.02)\end{array}$ & - & $\begin{array}{l}1.53 \pm 1.26 \\
(0.14-4.07)\end{array}$ & - & - & South Brazil & 11,17 \\
\hline $\mathrm{C}(4)$ & $\begin{array}{c}15.92 \pm 12.45 \\
(4.58-30.41)\end{array}$ & $\begin{array}{l}0.97 \pm 0.21 \\
(0.87-1.26)\end{array}$ & $\begin{array}{c}25.74 \pm 8.37 \\
(17.84-36.39)\end{array}$ & $\begin{array}{l}5.12 \pm 0.74 \\
(4.25-6.04)\end{array}$ & $\begin{array}{c}21.25 \pm 1.35 \\
(20.35-23.26)\end{array}$ & $\begin{array}{c}0.80 \pm 0.63 \\
(0.07-1.88)\end{array}$ & $\begin{array}{c}\text { Southeast } \\
\text { Brazil }\end{array}$ & This study \\
\hline $\mathrm{C}(2)$ & $\begin{array}{c}79.0 \\
(27.0-130.0)\end{array}$ & $\begin{array}{c}0.70 \\
(0.68-0.71)\end{array}$ & $\begin{array}{c}40.6 \\
(33.3-47.9)\end{array}$ & $\begin{array}{c}30.9 \\
(5.89-56.0)\end{array}$ & $\begin{array}{c}2.58 \\
(0.037-5.12)\end{array}$ & $\begin{array}{c}1.5 \\
(0.73-2.20)\end{array}$ & South Brazil & 7 \\
\hline
\end{tabular}

( $\mathrm{A}=$ Sotalia guianensis $; \mathrm{B}=$ Pontoporia blainvillei $; \mathrm{C}=$ Stenella frontalis $)$; Wet mass basis concentration was converted to dry mass basis concentration assuming that moisture content was $69.7 \%^{48} ; \mathrm{N}$-number of individuals.

Data concerning lead concentrations in the liver of cetaceans species ( $S$. guianensis, P. blainvillei and $S$. frontalis) are still limited in the literature. ${ }^{714}$ Hepatic lead concentrations found in this study were considerable higher than those found in S. guianensis and P. blainvillei from the coast of Paraná State in the Southern Brazil ${ }^{7}$ (Table 4) and also from the coast of Ceará State in the Northeast Brazil $^{14}$ (Table 4). This same behavior was observed for S. frontalis.

The comparison with literature data is useful and necessary once; the number of individuals available in this kind of studies is often small and also, few studies are conducted to determine a variety of trace elements in cetaceans from South American coast (see Table 4) However, several variability factors, though, should be taken into account even within the same species: sex of the individuals, feeding habits, life span, the site of sampling and method of analysis. ${ }^{41}$

Due to the small sample population of the cetacean species that occur on continental shelf ( $S$. frontalis), discussion about gender and body length differences in hepatic trace element concentrations was confined to cetaceans with coastal habits, S. guianensis and $P$. blainvillei.

Concentrations of essential (As, $\mathrm{Cu}$ and $\mathrm{Se}$ ) and nonessential $(\mathrm{Cd}, \mathrm{Pb}$ and $\mathrm{Ag})$ elements in the liver of females was not significantly different $(p>0.05)$ from those found in the liver of males from coastal species, S. guianensis and P. blainvillei. According to the review of O'Shea, ${ }^{26}$ generally, marine mammals, such as cetaceans present no gender differences in the accumulation of trace elements, as seen for these same cetaceans species from different Brazilian coastal areas. ${ }^{7,14}$

Data analysis from the two coastal species ( $S$. guianensis and P. blainvillei) showed that only hepatic Se concentrations increased with body length, presenting a significant positive relationship $(p<0.05)$, while no significant correlations $(p>0.05)$ were found between body length and hepatic $\mathrm{As}, \mathrm{Cu}$ and $\mathrm{Pb}$ concentrations in both species. Only, S. guianensis showed a significant positive relationship $(p<0.05)$ between Ag concentration and its body length, whereas cadmium concentrations increased significantly $(p<0.05)$ with body length in the liver of $P$. blainvillei. 
Previous studies also presented a significant relationship between hepatic trace element concentrations $(\mathrm{Cd}, \mathrm{Pb}$, $\mathrm{Se}$ and $\mathrm{Ag}$ ) and body length of $S$. guianensis ${ }^{7,14}$ and $P$. blainvillei. ${ }^{7,11,17,34}$ However, in the literature, the correlation between hepatic arsenic concentration and body length is still unclear for marine mammals, ${ }^{45}$ and limited information is available for $P$. blainvillei. ${ }^{7,11}$ Generally, no significant correlation was found between body length and arsenic concentrations in the liver of $P$. blainvillei.$^{7,11}$

Ikemoto et al. ${ }^{46}$ related that in general in long-lived marine mammals, the hepatic trace element concentrations increases with age, since the biological half-life is rather long in animals, due to age-related increase in concentration, and the strong affinity of some trace elements (e.g. $\mathrm{Cd}, \mathrm{Pb}$ and $\mathrm{Ag}$ ) to $\mathrm{SH}$ group in cysteine.

Even though not observed in this study, a significant decrease on hepatic concentrations of copper with body length has been reported for Sotalia guianensis from the coast of Paraná State in the Southern Brazil. ${ }^{7}$ According to Woshner et al., ${ }^{8}$ the decline in tissue $\mathrm{Cu}$ with age could result from loss of $\mathrm{Cu}$ over time, dilution of $\mathrm{Cu}$ levels by increased tissue mass with age (body length), or decreased tissue level requirements for $\mathrm{Cu}$ (i.e., metabolic regulation).

Discriminant Function Analysis was applied to compare the concentrations of trace elements (variables) between the cetacean species (groups). The variable that more contribute to discriminant analysis was $\mathrm{Pb}(p<0.01)$. Squared Mahalanobis Distances always were high between the groups that represent cetaceans with coastal habit (S. guianensis and P. blainvillei) and oceanic habit (S. frontalis): ( $S$. guianensis x S. frontalis, $\mathrm{F}=467.0$; $\left.\mathrm{D}^{2}=985.0 ; p<10^{-8}\right) ;($ P. blainvillei $\mathrm{x}$ S. frontalis, $\mathrm{F}=478.0$; $\left.\mathrm{D}^{2}=1042.0 ; p<10^{-8}\right)$, indicating that significant differences $\left(p<2 \times 10^{-8}\right)$ were observed among these groups with an 89.5 percent correct classification. However no significant difference was observed between the groups that represent cetaceans with coastal habit (S. guianensis and P. blainvillei) since that Squared Mahalanobis Distances always were low (S. guianensis x P. blainvillei, $\mathrm{F}=2.4$; $\left.\mathrm{D}^{2}=1.64 ; p>0.05\right)$ when compared with the group of cetaceans with oceanic habit. Scatter plot of Canonical Variables (Figure 2) showed a distinct formation of two different groups: one represented by species with coastal habit (S. guianensis and P. blainvillei) and another by species with oceanic habit ( $S$. frontalis), indicating that these cetaceans presented different behavior for accumulation of trace elements by the liver. Although a number of physiological and environmental factors may also have some influence, the feeding behavior (based on fish and cephalopods rich in trace elements) and the

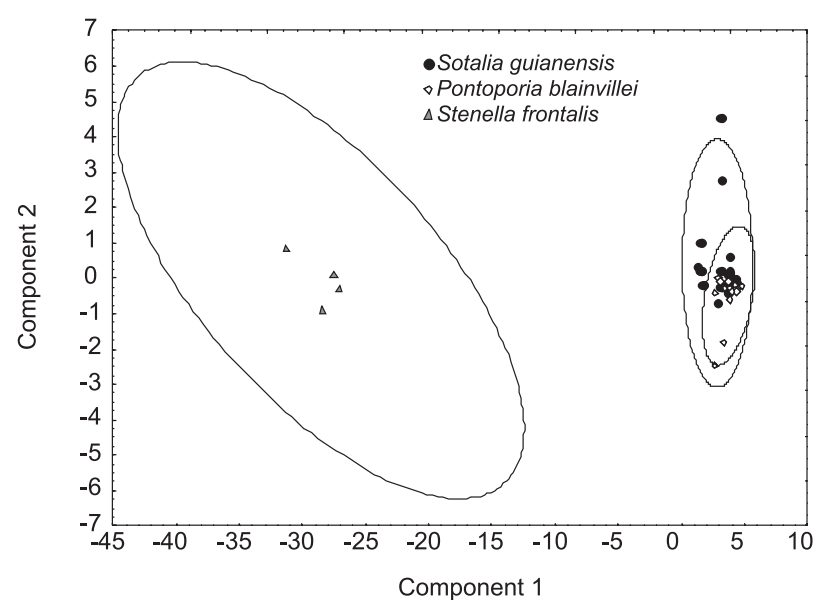

Figure 2. Scatter plot of Canonical Variables for S. guianensis, P. blainvillei and $S$. frontalis (89.5 percent correct classification).

complexity of the marine food chain are the major factors responsible for the bioaccumulation of trace elements in long-lived marine animals. ${ }^{3,25,45,47}$

\section{Conclusions}

The present study adds new insight to and complements the existing studies on trace element concentrations in the liver of cetaceans from the South American coast. Relatively low concentrations of some trace elements were found in the liver of coastal cetaceans (S. guianensis and $P$. blainvillei) when compared with the same species from the Argentina coast and also, when compared with a cetacean species that occur on continental shelf (S. frontalis). However, cetacean species from the north of Rio de Janeiro that has coastal habit (S. guianensis and P. blainvillei) did not present different behavior for accumulation of trace elements by the liver.

Based on the results, it is possible to conclude that, not only the different environmental conditions, but also total length and mainly the feeding habit influenced the accumulation of trace elements by the liver of cetaceans. Conversely, gender did not influence on the accumulation of trace elements by the liver of cetacean species.

\section{Acknowledgments}

The authors are grateful to the financial support of the Fundação Carlos Chagas Filho de Amparo à Pesquisa do Estado do Rio de Janeiro (FAPERJ Proc 171.352/2006) and the Conselho Nacional de Desenvolvimento Científico e Tecnológico (CNPq Proc 471434/2006-0). H.A. Kehrig and A.P.M. Di Beneditto were sponsored by CNPq (151634/2006-8 and PQ 305160/2006-0). 


\section{References}

1. Sures, B.; Taraschewski, H.; Haug, C.; Anal. Chim. Acta 1995, 311, 135.

2. Srogi, K.; Anal. Lett. 2008, 41, 677.

3. Shibata, Y.; Morita, M.; Fuwa, K.; Adv. Biophys. 1992, 28, 31.

4. Eisler, R.; Selenium Hazards to Fish, Wildlife and Invertebrates: A Synoptic Review; U.S. Fish and Wildlife Service Biological Report 85, 2000(1.5), p. 57.

5. Kannan, K.; Agusa, T.; Perrotta, E.; Thomas, N. J.; Tanabe, T.; Chemosphere 2006, 65, 2160.

6. Lane, T. W.; Saito, M. A.; George, G. N.; Pickering, I. J.; Prince; R. C.; Morel, F. M. Nature 2005, 435, 42.

7. Kunito, T.; Nakamura, S.; Ikemoto, T.; Anan, Y.; Kubota, R.; Tanabe, S.; Rosas, F. C. W.; Fillmann, G.; Readman, J. W.; Mar. Pollut. Bull. 2004, 49, 574.

8. Woshner, V. M.; O’Hara, T. M.; Bratton, G. R.; Suydam, R. S.; Beasley, V. R.; J. Wildl. Dis. 2001, 37, 693.

9. Thompson, B.; Adelsbach, T.; Brown, C.; Hunt, J.; Kuwabara, J.; Neale, J.; Ohlendorf, H.; Schwarzbach, S.; Spies, R.; Taberski, K.; Environ. Res. 2007, 105, 156.

10. Capelli, R.; Drava, G.; De Pellegrini, R.; Minganti, V.; Poggi, R.; Adv. Environ. Res. 2000, 4, 31.

11. Seixas, T. G.; Kehrig, H. A.; Fillmann, G.; Di Beneditto, A. P. M.; Souza, C. M. M.; Secchi, E. R.; Moreira, I.; Malm, O.; Sci. Total Environ. 2007, 385, 208.

12. Frodello, J. P.; Romeo, M.; Viale, D.; Environ. Pollut. 2000, $108,447$.

13. Lailson-Brito, J.; Azeredo, M. A. A.; Malm, O.; Ramos, R. A.; Di Beneditto, A. P. M.; Saldanha, M. F. C.; LAJAM 2002, 1, 107.

14. Monteiro-Neto, C.; Itavo, R. V.; Moraes, L. E. S.; Environ. Pollut. 2003, 123, 319.

15. Kehrig, H. A.; Seixas, T. G.; Baêta, A. P.; Lailson-Brito, J.; Moreira, I.; Malm, O.; RMZ-M\&G 2004, 51, 1111.

16. Dorneles, P. R.; Lailson-Brito, J.; Santos, R. A.; Costa, P. A. S.; Malm, O.; Azevedo, A. F.; Torres, J. P. M.; Environ. Pollut. 2007, 148, 352.

17. Seixas, T. G.; Kehrig, H. A.; Costa, M.; Fillmann, G.; Di Beneditto, A. P. M.; Secchi, E. R.; Souza, C. M. M.; Malm, O.; Moreira, I.; Environ. Pollut. 2008, 154, 98.

18. André, J.M.; Ribeyre, F.; Boudou, A.; Mar. Environ. Res. 1990, $30,43$.

19. Leonzio, C.; Focardi, S.; Fossi, C.; Sci. Total Environ. 1992, 119, 77.

20. Augier, H.; Park, W. K.; Ronneau, C.; Mar. Pollut. Bull. 1993, 26, 306.

21. Caurant, F.; Amiard, J. C.; Amiard-Triquet, C.; Sariau, P.; Mar. Ecol. Prog. Ser. 1994, 103, 207.

22. Becker, P. R.; Mackey, E. A.; Demiralp, R.; Suydams, R.; Early, G.; Koster, B. J.; Wise, S. A.;. Mar. Pollut. Bull. 1995, 30,262 .
23. Dietz, R.; Riget, F.; Johansen, P.; Sci. Total Environ. 1996, 186, 67.

24. Wagemann, R.; Innes, S.; Richard, P. R.; Sci. Total Environ. 1996, 186, 41.

25. Monaci, F.; Borre, A.; Leonzio, C.; Marsili, L.; Calzada, N.; Environ. Pollut. 1998, 99, 61.

26. O'Shea, T. J. In Environmental Contaminants and Marine Mammals; Reynolds III, J. E.; Rommel, S. A., eds.; Smithsonian Institution Press: Washington, 1999, p. 485.

27. Cardellicchio, N.; Decataldo, A.; Di Leo, A.; Misino, A.; Environ. Pollut. 2002, 116, 265.

28. Roditi-Elasar, M.; Kerem, D.; Hornung, H.; Kress, N.; ShohamFrider ,E.; Goffman, O.; Spanier, E.; Mar. Pollut. Bull. 2003, 46, 503.

29. Dehn, L.; Follmann, E. H.; Thomas, D. L.; Sheffield, G. G.; Rosa, C.; Duffy, L. K.; O’Hara, T. M.;. Sci. Total Environ. 2006, $362,103$.

30. Stockin, K. A.; Law, R. J.; Duignan, P. J.; Jones, G. W.; Porter, L.; Mirimin, L.; Meynier, L.; Orams, M. B.; Sci. Total Environ. 2007, 387, 333.

31. Kemper, C.; Gibbs, P.; Obendorf, D.; Marvanek, S.; Lenghaus, C.; Sci. Total Environ. 1994, 142, 129.

32. Marcovecchio, J. E.; Gerpe, M. S.; Bastida, R.; Rodriguez, D. H.; Morón, S. G.; Sci. Total Environ. 1994, 154, 141.

33. De Moreno, J. E. A.; Gerpe, M. S.; Moreno, V. J.; Vodopivez, C.; Polar Biol. 1997, 17, 131.

34. Gerpe, M. S.; Rodriguez, D. H.; Moreno, V. J.; Bastida, R. O.; Moreno, J. A. E.; LAJAM 2002, 1, 95.

35. Lavery, T. J.; Butterfield, N. Kemper, C. M.; Reid, R. J.; Sanderson, K.; Sci. Total Environ. 2008, 390, 77.

36. Di Beneditto, A. P. M.; Ramos, R. M. A.; J. Mar. Biol. Ass. UK. 2004, 84, 1245.

37. Schwartz, J.; Aldridge, B.; Blanchard, M.; Mohr, F. C.; Stott, J.; Vet. Immunol. Immunopathol. 2005, 104, 1.

38. Muehe, D.; Vallentini, E.; O Litoral do Estado do Rio de Janeiro: Uma Caracterização Físico-Ambiental, FEMAR: Rio de Janeiro, 1998, p. 99.

39. Di Beneditto, A. P. M.; Ramos, R. M. A.; J. Cet. Res. Manage 2001, 3, 185.

40. Di Beneditto, A. P. M.; Ramos, R. M. A.; Siciliano, S.; Santos, R. A.; Bastos, G.; Fagundes-Netto, E.; Aquatic Mammals 2001, $27,24$.

41. Capelli, R.; Das, K.; De Pellegrini, R.; Drava, G.; Lepoint, G.; Miglio, C.; Minganti, V.; Poggi, R.; Sci. Total Environ. 2008, $390,569$.

42. Nigro, M.; Leonzio, C.; Mar. Ecol-Prog. Ser. 1996, 135, 137.

43. Di Beneditto, A. P. M.; Ramos, R. M. A.; Lima, N. R.; Braz. Arch. Biol. Technol. 2001, 44, 291.

44. Moreno, I. B.; Zerbini, A. N.; Danilewicz, D.; Santos, M. C. O.; Simões-Lopes, P. C.; Lailson-Brito, J.; Azevedo, A. F.; Mar. Ecol. Prog. Ser. 2005, 300, 229. 
45. Kubota, R.; Kunito, T.; Tanabe, S.; Environ. Pollut. 2001, 115, 303.

46. Ikemoto, T.; Kunito, T.; Watanabe, I.; Yasunaga, G.; Baba, N.; Miyazaki, N.; Petrov, E. A.; Tanabe, S.; Environ. Pollut. 2004, 127, 83 .
47. Bustamante, P.; Caurant, F.; Fowler, S. W.; Miramand, P.; Sci. Total Environ. 1998, 220, 71.

48. Yang, J.; Miyazaki, N.; Environ. Pollut. 2003, 121, 345.

Received: June 18, 2008

Web Release Date: December 12, 2008 